\title{
Potential Inoculum Sources and Incidence of Strawberry Soilborne Pathogens in Spain
}

Ana María Pastrana, María José Basallote-Ureba, Ana Aguado, and Nieves Capote, IFAPA Centro Las Torres-Tomejil, Apdo. Oficial, 41200 Alcalá del Río, Sevilla, Spain

\begin{abstract}
The decline and death of strawberry plants in Spanish fruit production fields have mainly been attributed to the soilborne pathogens Macrophomina phaseolina, Phytophthora cactorum, and Fusarium spp. Inoculum sources of M. phaseolina and $P$. cactorum, and the incidence all three genera, were investigated in nurseries and fruit production fields over three consecutive seasons. M. phaseolina inoculum sources consisted of fumigated preplant fruit production soils (50\%) and fumigated nursery soils $(47 \%)$, although the pathogen could not be detected in nursery mother and runner plants. $P$. cactorum inoculum sources included nursery $(20 \%)$ and preplant fruit production (17\%) fumigated soils, and

nursery runner plants (up to $15 \%$ ). In fruit production plants, the average incidence of M. phaseolina and P. cactorum were 4.2 and $3.7 \%$, respectively. Fusarium spp. inoculum sources could not be accessed extensively due to the lack of effective quantitative real-time PCR assays. Limited testing of nursery plants showed that Fusarium oxysporum f. sp. fragariae (Fof) was absent. In field production plants and soil, F. solani was the main pathogenic Fusarium spp., with Fof only identified once in a fruit production plant. Ineffectively fumigated soils in nurseries and production fields, along with infected runner plants, can be inoculum sources of soilborne strawberry pathogens in Spain.
\end{abstract}

Spain is the largest producer of strawberry (Fragaria $\times$ ananassa Duch.) plants and fruits in Europe. Strawberry runners from mother plants are grown in high-elevation nurseries in northern Spain, mainly Segovia, Ávila, and Valladolid provinces, where optimal agroclimatic conditions prevail from March to September. Runner plants from nurseries are uprooted and transplanted into fruit production fields located mainly in southwestern Spain (Huelva Province), where plants develop and fruit from October to May-June, mainly under plastic macrotunnels.

Reduced yields due to plant diseases have increased alarmingly in these strawberry fruit production fields in recent years (Chamorro et al. 2015; Pérez-Jiménez et al. 2012). The losses are reportedly the result of soilborne pathogens such as Macrophomina phaseolina (Tassi) Goid., the causal agent of charcoal rot (Avilés et al. 2008); Phytophthora cactorum (Leb. \& Cohn), causing strawberry crown rot (de los Santos et al. 2002) and leather rot of fruit (Maas 1998); Fusarium oxysporum f. sp. fragariae Winks \& Y.N. Williams (Fof), causing Fusarium wilt (Arroyo et al. 2009); and F. solani (Mart.) Sacc. causing crown and root rot (Pastrana et al. 2014). The recent emergence of these fungal diseases in strawberry has been related largely to the phasing out of more than $70 \%$ of chemical soil fumigants used in the European Union, including methyl bromide $(\mathrm{MeBr})$, in accordance with the Montreal Protocol (Martin 2003).

The detection and accurate identification of plant pathogens are among the most important strategies to control plant diseases and to develop and apply preventative control measures (Capote et al. 2012). In strawberry crop management, special attention should be given to the early detection of pathogens in propagation plant material (mother and runner plants) to avoid the introduction and further spread of pathogens in a growing area where the disease is not present yet. The ability of many soilborne fungi and oomycetes to form resistant structures that survive in the soil for long periods causes difficulties in eradicating the pathogens once they have become established, making infested soils another main source of pathogen inoculum. Traditional methods to detect and identify pathogens have

Corresponding author: Nieves Capote,

Email: marian.capote@juntadeandalucia.es

Accepted for publication 24 December 2016.

C 2017 The American Phytopathological Society often relied on visual inspection of symptoms or on pathogen isolation using selective media. However, the visual symptoms of $M$. phaseolina, $P$. cactorum, and Fusarium spp. in strawberry plants are nearly indistinguishable, consisting of plant wilting, chlorosis, drying of leaves, and eventual collapse of plants. Morphological identifications of plant pathogenic fungi are time-consuming and rely on labor-intensive techniques and taxonomic expertise. These limitations have led to the development of new diagnostic methods and protocols for detecting plant pathogens based on molecular techniques. In addition, the quantification of pathogens represents an important aspect of plant disease management (Mirmajlessi et al. 2015). For this reason, quantitative real-time PCR (qPCR) has emerged as the gold standard method for identifying and quantifying fungal and oomycete pathogens, due to its accuracy, speed, and high throughput (Capote et al. 2012).

qPCR TaqMan-based methods have been developed to detect and quantify M. phaseolina and P. cactorum in plant and soil samples (Babu et al. 2011; Li et al. 2013). To improve the above-cited protocols and use them as effective and rapid diagnostic techniques, we developed a simple and direct sample-preparation method based on the dilution of crude plant extracts. The protocol excludes the DNA-extraction step, saving labor and time while facilitating the diagnosis of large numbers of plant samples. In the current study, the aforementioned detection and quantification protocols were used to determine the possible sources of inoculum (nursery mother and runner plants, fumigated nursery soils, and fumigated preplant field production soils) of $M$. phaseolina and $P$. cactorum in strawberries in Spain. The incidence of these pathogens was also determined in field production soils at the end of the cropping season (postharvest) and in field production plants.

No qPCR method has yet been successfully developed to specifically detect $F$. oxysporum f. sp. fragariae. The $F$. oxysporum species complex includes pathogenic and nonpathogenic strains that are morphologically indistinguishable (O'Donnell et al. 2009). To differentiate between pathogenic and nonpathogenic isolates, Suga et al. (2013) developed PCR primers (FofraF and FofraR) to amplify a specific DNA sequence from $F$. oxysporum $\mathrm{f}$. sp. fragariae. However, a subset of isolates diagnosed as pathogenic by PCR did not produce symptoms in strawberry in pathogenicity tests, and vice versa (Henry et al. 2017; Suga et al. 2013). Li et al. (2014) also developed qPCR primers that target the FOW1-gene involved in F. oxysporum pathogenesis that encodes a mitochondrial carrier protein required specifically for the colonization of plant-root tissue by $F$. oxysporum. However, the study did not perform any test to verify whether this 
method discriminates between pathogenic and nonpathogenic $F$. oxysporum isolates. Due to the lack of a qPCR method to specifically detect $F$ of and because of the recent report of $F$. solani also contributing to the decline and death of strawberry plants under cultivation (Pastrana et al. 2014), isolation studies and pathogenicity tests must be conducted to determine the importance of Fusarium spp. in strawberries. Therefore, the aim of the current study was to assess the importance of Fusarium species in contributing to the Fusarium diseases in Spanish strawberry crops. Fusarium isolates, mainly obtained from fruit production plants and soil, were evaluated for pathogenicity, with a limited number of isolates from nursery plants also being tested. The Fof PCR primer pair of Suga et al. (2013) was also evaluated on the $F$. oxysporum isolates included in the pathogenicity tests, to determine if the assay might have potential for identifying Fof in Spanish strawberry production regions. Altogether, the information can be used in future to facilitate the development of methods for evaluating the potential inoculum sources of Fusarium spp. in strawberries in Spain.

\section{Materials and Methods}

Soil sampling and assessment. Soil samples from nurseries. Soil samples were collected at three high-elevation nurseries over three consecutive seasons (2011-12, 2012-13, and 2013-14) for the detection and quantification of $M$. phaseolina and $P$. cactorum. The nurseries were located in the provinces of Segovia, Ávila, and Valladolid (Spain). For each nursery, two fumigated and two nonfumigated plots were analyzed, except for the Ávila nurseries where two fumigated soils were analyzed the first season and one fumigated and one nonfumigated soil the following two seasons. A total of 15 fumigated and 13 nonfumigated soils were thus investigated in the three localities over the three seasons. Plots from the Segovia and Valladolid nurseries were fumigated with 1,3-dichloropropene:chloropicrin $(1,3 \mathrm{D}: \mathrm{CP})(50: 50, \mathrm{v} / \mathrm{v})$, whereas 3,5-dimethyl-1,3,5-thiadiazinane2-thione (Dazomet) was used in the Ávila plots. Fumigation was conducted by injection of 1,3D:CP or Dazomet (500 liters/ha) into the soil at 20 to $25 \mathrm{~cm}$ depth under a plastic mulch. Due to the 3-year crop rotation applied at the nurseries, analyzed fumigated and nonfumigated plots were not the same each season. Nonfumigated plots were cultivated with strawberry plants the previous season. Soil samples were collected 1 month after fumigation from fumigated and nonfumigated plots, which was approximately 1 to 2 weeks prior to planting of the strawberry runner plants. Twelve samples $(0$ to $20 \mathrm{~cm}$ depth, approximately $100 \mathrm{~g}$ ) taken at random in each plot and season were pooled and mixed as a composite sample. Soil samples were airdried for 7 to 10 days at room temperature, passed through a $1 \mathrm{~mm}$ mesh sieve, and stored at $5{ }^{\circ} \mathrm{C}$ until used. Three replicates per plot were analyzed.

For DNA extraction, soil samples were homogenized in a mortar. DNA was extracted from $250 \mathrm{mg}$ soil, with three extraction replicates per sample using the MoBio PowerSoil DNA Isolation Kit (MoBio Laboratories, Solana Beach, CA) following the manufacturers' instructions. The DNA concentration was determined on a ND-1000 NanoDrop spectrophotometer (NanoDrop Products, Wilmington, DE). Five microliters of the extracted DNA was used as template DNA for qPCR detection and quantification of $M$. phaseolina and $P$. cactorum (see below). The results of qPCR (pg pathogen DNA/g of soil) analyses are presented as the average and standard error of fumigated or nonfumigated plots in each province and season.

Soil samples from fruit production fields. Soil samples were collected in two strawberry fruit production fields situated in different geographic locations in Huelva Province, namely Cartaya and Palos de la Frontera (hereafter, Palos). Soils were fumigated in August with 1,3:CP (500 liters/ha) through the drip irrigation system under beds covered with a black polyethylene plastic film. The same three macrotunnels per field were sampled each season. From the strawberry beds, 30 soil samples (0 to $20 \mathrm{~cm}$ in depth, approximately $100 \mathrm{~g}$ ) per macrotunnel were taken in 1,3:CP fumigated soils in October, approximately 2 months after fumigation and 1 or 2 weeks prior to planting and at the end of the harvest season (May-June). All the samples from each macrotunnel were pooled and used as a composite soil sample for further analysis. Three replicates per macrotunnel were analyzed for qPCR-detection and quantification of $M$. phaseolina and $P$. cactorum as described for the nursery soil samples. Results of qPCR (pg pathogen DNA/g of soil) analyses are presented as the average and standard error of three replicates in the three macrotunnels analyzed per field and season.

For soil assays for Fusarium spp. isolation, $5 \mathrm{~g}$ of fumigated or nonfumigated soil were added to a flask containing $150 \mathrm{ml}$ of $0.1 \%$ water agar (WA) (Difco) and placed on a stir plate for $1 \mathrm{~min}$. Before the stirring ended, $1 \mathrm{ml}$ of the suspension was removed and spread on V8 agar plates (5 plates/soil sample) and incubated at $25^{\circ} \mathrm{C}$ for 2 days in darkness and 3 additional days with a $12 \mathrm{~h}$ photoperiod (OSRAM L $18 \mathrm{~W} / 21-840$ Hellweiss Lumilux Cool White, $\left.75 \mu \mathrm{E} \mathrm{m}^{-2} \mathrm{~s}^{-1}\right)$. Fusarium-like colonies were transferred to PDA plates and single-spore isolates were obtained for further morphological, molecular, and pathogenicity characterization.

Plant sampling and assessment. Plant samples from nurseries. Asymptomatic mother plants were collected from the same nurseries from which soil samples were taken in the Segovia, Ávila, and Valladolid provinces. A total of 314, 180, and 207 mother plants were analyzed, respectively, in the 2011-12, 2012-13, and 2013-14 seasons for M. phaseolina and $P$. cactorum through qPCR-assays, and using plate-culture isolations for Fusarium spp. The mother plants analyzed corresponded to 12 different strawberry cultivars (Amiga, Benicia, Candonga, Camarosa, Merced, Sabrina, Favette, Festival, Florida Fortuna, Primoris, San Andreas, and Viva Patricia).

Plant samples were washed under tap water and cut longitudinally in half. One half ( 0.5 to $2 \mathrm{~g}$ of fresh weight) was ground into individual extraction bags (Bioreba, Switzerland) in the presence of 1:10 (w/v) $1 \times$ PBS buffer, $\mathrm{pH} 7.2$ supplemented with $2 \%(\mathrm{w} / \mathrm{v})$ polyvinyl pyrrolidone (PVP-40) and $0.2 \%$ (w/v) sodium diethyl dithiocarbamate (DIECA). Plant tissue was homogenized with a hand roller to obtain a crude extract. Crude extracts were incubated for $10 \mathrm{~min}$ at $95^{\circ} \mathrm{C}$ and frozen at $-80^{\circ} \mathrm{C}$ until used. Dilutions of plant crude extracts in sterile distilled water $(1: 20 \mathrm{v} / \mathrm{v})$ were directly used as the template DNA $(5 \mu \mathrm{l})$ for qPCR reactions for the specific detection of $M$. phaseolina and $P$. cactorum (see below). The other longitudinal half part of the plant was used for plate culture isolations of Fusarium spp. Crown, root, and petiole segments $(0.5$ to $1 \mathrm{~cm})$ were surface sterilized in $1 \%$ sodium hypochlorite for $2 \mathrm{~min}$, rinsed in sterile distilled water, air dried, placed onto PDA, and incubated at $25^{\circ} \mathrm{C}$ for 2 days in darkness and 5 days at a $12 \mathrm{~h}$ photoperiod. Colonies identified as Fusarium spp. on PDA were streaked on water agar, and single-spore subcultures were stored at $-80^{\circ} \mathrm{C}$ until further characterization.

Asymptomatic runner plants were collected from the same three strawberry nurseries from which mother plants were sampled. An additional 20 other nurseries were also sampled that were located in Segovia, Ávila, and Valladolid provinces. A total of 480, 200, and 340 runner plants were analyzed, respectively, in the three respective seasons, as described for the mother plants. The plants analyzed corresponded to 13 different strawberry cultivars (Amiga, Antilla, Benicia, Camarosa, Candonga, Festival, Florida Fortuna, Honor, Merced, Primoris, Sabrina, San Andreas, and Splendor).

Plant samples from fruit production fields. Symptomatic (declining and dead) fruit-production plants cv. Sabrina, Florida Fortuna, Splendor, and Primoris were sampled throughout Huelva Province, mainly Cartaya and Palos, over three production seasons during 2011-12, 2012-13, and 2013-14. A total of 452, 1,249, and 719 plants were analyzed, respectively, using plate-culture isolations of M. phaseolina, P. cactorum, and Fusarium spp., as described above for Fusarium spp.

Detection and quantification of $M$. phaseolina and $P$. cactorum by qPCR. Five microliters $(\mu 1)$ of DNA extracted from nursery and fruit producing field soils (three replicates/sample), or $5 \mu$ l diluted plant crude extract from mother and runner plants (two replicates/ plant) were used to detect and quantify $M$. phaseolina and $P$. cactorum. The qPCR reactions were performed in 96-well plates in a Chromo 4 thermocycler (Bio-Rad). Reaction cocktails contained $1 \times$ SensiMix (SensiMix Probe No-Rox Kit, Bioline), $900 \mathrm{nM}$ each forward and reverse primers, $150 \mathrm{nM}$ TaqMan probe (Table 1), 
and $1 \mathrm{mg} / \mathrm{ml} \mathrm{BSA}$. Amplifications were carried out at $95^{\circ} \mathrm{C}$ for $10 \mathrm{~min}$, and 45 cycles of $15 \mathrm{~s}$ at $95^{\circ} \mathrm{C}$ and $60 \mathrm{~s}$ at $61^{\circ} \mathrm{C}$ for both pathogens. Distilled water was used for negative controls. Standard curves were constructed by amplifying 10-fold serial dilutions (50 ng to $50 \mathrm{fg}$ ) of genomic DNA from M. phaseolina M-16 or $P$. cactorum PF-305 diluted in healthy plant crude extract (1:10 dilution) or in DNA from sterile soil $(20 \mathrm{ng} / \mu \mathrm{l})$ for detection and quantification of the pathogens in plant material and soil samples, respectively. The efficiency of the reactions and $\mathrm{R}^{2}$ values were calculated from the slope of the plant and soil DNA standard curves, and these were all within acceptable norms for the M. phaseolina (efficiency $=101.2 \% ; \mathrm{R}^{2}=0.998$ ) and $P$. cactorum (efficiency = $99.7 \% ; \mathrm{R}^{2}=0.991$ ) assays. An internal positive control (IPC) was used to rule out false negative amplifications. For the IPC assay, $0.05 \mathrm{ng}$ of lambda $(\lambda)$ bacteriophage DNA was added to each sample and amplified in parallel SYBRGreen-qPCR reactions. The IPC reaction cocktail contained 1× SensiMix (SensiMix SYBRGreen NoRox, Bioline), $50 \mathrm{nM} \lambda$ primers (Table 1) that were designed using Primer Express version 2.0,1 mg/ml BSA, and $5 \mu \mathrm{l}$ of diluted plant crude extract or genomic DNA from soil samples. Amplification conditions were the same as for M. phaseolina and P. cactorum.

Morphological and molecular characterization of Fusarium spp., M. phaseolina, and $\boldsymbol{P}$. cactorum isolates. Single-spore cultures from 88 selected Fusarium spp. isolates recovered from preplanting and postharvest production field soils (five isolates), and nursery (12 isolates) and fruit production plants (71 isolates) (Table 2) were cultured on PDA and on $0.6 \% \mathrm{KCl}$ agar (CorpasHervias et al. 2006) at $25^{\circ} \mathrm{C}$ for 2 days in darkness, and 8 additional days at a 12-h photoperiod. Colony morphology and morphological characteristics were recorded under an optical microscope to identify isolates to the genus or species level using standard descriptions (Leslie and Summerell 2006). For molecular characterization, DNA from single-spore cultures from the 88 selected isolates was isolated using the Isolate II Plant DNA Kit (Bioline, London) following the manufacturer's instructions with some modifications. This first consisted of a small amount of fungal mycelium growing on PDA being scraped from the plate and placed into a centrifuge tube containing lysis buffer (Bioline), followed by homogenization with a pistil coupled to an electric drill. The subsequent DNA extraction steps were performed as described in the instruction manual. The DNA concentration was determined on an ND-1000 NanoDrop spectrophotometer (NanoDrop Products, Wilmington, DE). Fusarium spp. isolates were identified by PCR amplification and sequencing of a portion of the $E F-1 \alpha$ gene using primers EF1 and EF2 (O'Donnell et al. 1998). The PCR reaction contained $1 \times$ Hi-Fi Buffer (Bioline), $2 \mathrm{mM} \mathrm{MgCl} 2,0.25 \mathrm{mM}$ each dNTP, $0.4 \mu \mathrm{M}$ each primer, 1 unit of velocity DNA polymerase (Bioline), and 50 to $100 \mathrm{ng}$ of genomic DNA. Amplifications were carried out at $95^{\circ} \mathrm{C}$ for $2 \mathrm{~min}$, and 35 cycles of $30 \mathrm{~s}$ at $95^{\circ} \mathrm{C}, 30 \mathrm{~s}$ at $59^{\circ} \mathrm{C}$, and $15 \mathrm{~s}$ at $72^{\circ} \mathrm{C}$. Sequences were compared with published sequences in GenBank and FusariumID databases by BLAST analysis.

$M$. phaseolina and $P$. cactorum single-spore isolates recovered from diseased fruit-production plants were also identified using morphological characteristics (Gallegly and Hong 2008; Sutton 1980), which was confirmed by sequencing of a portion of the $E F-1 \alpha$ gene for M. phaseolina using primers EF446f and EF1035r (Inderbitzin et al. 2005) and a portion of the internal transcribed spacer (ITS) of the nuclear ribosomal DNA for $P$. cactorum using primers ITS6 and ITS7 (Cooke et al. 2000). Sequences were compared using BLAST analyses in the GenBank database, where only published peer reviewed sequences were considered for reliable species identifications.

Pathogenic characterization of Fusarium spp. isolates. To assess pathogenicity, 70 out of 88 Fusarium spp. isolates recovered from preplanting and postharvest field production soils, field production plants, and nursery runner plants were tested (Table 2). Singlespore isolates were cultured in potato dextrose broth (PDB) in a rotary shaker $(150 \mathrm{rpm})$ at $25^{\circ} \mathrm{C}$ with a 12 -h photoperiod for 10 days. The spore suspension was filtered through four layers of cheesecloth and adjusted to $10^{6}$ conidia/ml with sterile distilled water using a hemocytometer. One-month-old strawberry seedlings cv. Camarosa from meristem cultures were inoculated by dipping roots and crowns in the conidial suspension for $30 \mathrm{~min}$. Control plants were inoculated by immersion in PDB/sterile distilled water $(1: 1, \mathrm{v} / \mathrm{v})$. Each plant was individually transplanted into a $13-\mathrm{cm}$ pot containing sterilized 1:9 perlite/peat moss $(\mathrm{v} / \mathrm{v})$. Plants were maintained for 3 months at $25 / 18^{\circ} \mathrm{C}$ and $60 / 40 \%$ relative humidity (day/night) in a growth chamber with a daily 16 -h photoperiod of fluorescent light, fertilized 15 days after inoculation with $0.3 \mathrm{~g}$ of Osmocote per pot and watered as required. Eight plants were inoculated for each Fusarium spp. isolate. Each pathogenicity test was conducted twice. Plants were placed in a completely randomized design. At the end of the experiment, plants were removed from the pots and infection severity was assessed according to: (i) percentage dead plants, (ii) percentage new roots, (iii) percentage crown rot, and (iv) plant fresh weight. Reisolation of the inoculated Fusarium spp. from roots, crowns, and petiole tissues was performed on PDA plates, as described above.

PCR identification of $\boldsymbol{F}$. oxysporum $\mathbf{f}$. sp. fragariae isolates. All isolates identified as $F$. oxysporum based on sequence analyses (Table 2) were also tested for PCR amplification of a 239-bp fragment specific for $F$. oxysporum $\mathrm{f}$. sp. fragariae using primers FofraF (5'-CAGACTGGGGTGCTTAAAGTT-3') and FofraR (5'AACCGCTAGGGTCGTAACAAA-3') (Suga et al. 2013). Amplification was conducted in a $10-\mu$ l volume with $1 \times$ BioTaq buffer (Bioline) $1 \times, 2 \mu \mathrm{M}$ each primer, 2.5 units of BioTaq polymerase (Bioline), and 50 to $100 \mathrm{ng}$ of genomic DNA. PCR was performed using the same cycling parameters described by Suga et al. (2013). PCR products were sized by electrophoresis in $2.5 \%$ agarose gels run in $0.5 \times$ TAE buffer, stained with RedSafe, and visualized and photographed over a UV transilluminator. Isolates previously confirmed by pathogenicity tests as $F$. oxysporum $\mathrm{f}$. sp. fragariae in Spain (G2-4) (Arroyo et al. 2009), Australia (ATCC 18138), and South Carolina (NRRL 26438) (O'Donnell et al. 2009) were also included in the assays. A Japanese Fof isolate (MAFF 744009) was used as positive control for the reaction (Suga et al. 2013).

Statistical data analyses. Student's $t$ test was used to compare variable means between fumigated and nonfumigated soils in nurseries and between preplanting and postharvest soils in fruit production fields from each studied season. The variables that were analyzed included the amount of $M$. phaseolina $\mathrm{DNA} / \mathrm{g}$ soil and $P$. cactorum DNA/g soil.

Table 1. Primers and probes used to detect and quantify Macrophomina phaseolina and Phytophthora cactorum in soil samples and strawberry plant crude extracts by qPCR. Primers sequences for an internal positive control, based on lambda bacteriophage, are also included

\begin{tabular}{|c|c|c|c|c|c|c|}
\hline Target species & $\begin{array}{l}\text { Oligo } \\
\text { name }\end{array}$ & Sequence $\left(5^{\prime} \rightarrow 3^{\prime}\right)$ & $\begin{array}{c}\text { Amplicon } \\
\text { size }\end{array}$ & Chemistry & $\begin{array}{l}\text { Target } \\
\text { gene }\end{array}$ & Reference \\
\hline \multirow{3}{*}{$\begin{array}{l}\text { Macrophomina } \\
\text { phaseolina }\end{array}$} & $\mathrm{MpTq}-\mathrm{F}$ & GCCTTACAAGGGTCTCGTCAT & \multirow[t]{3}{*}{$150 \mathrm{bp}$} & \multirow[t]{3}{*}{ TaqMan } & \multirow[t]{3}{*}{ SCAR } & \multirow[t]{3}{*}{ Babu et al. 2011} \\
\hline & MpTq-R & CCCTTGGCGATGCCGATA & & & & \\
\hline & MpTq-P & FAM-CAGGCCACAGGATCTT-MGB & & & & \\
\hline \multirow{3}{*}{$\begin{array}{l}\text { Phytophthora } \\
\text { cactorum }\end{array}$} & Ypt-cac-F3 & CATGGCATTATCGTGGTGTA & \multirow[t]{3}{*}{$122 \mathrm{bp}$} & \multirow[t]{3}{*}{ TaqMan } & \multirow{3}{*}{$\begin{array}{l}\text { ras protein } \\
(Y p t 1)\end{array}$} & \multirow[t]{3}{*}{ Li et al. 2013} \\
\hline & Ypt-cac-R3 & GCTCTTTTCCGTCGGC & & & & \\
\hline & P-cac4 & VIC-CGGACCAGGAGTCGTTCAACAAC-MGB & & & & \\
\hline \multirow{2}{*}{$\begin{array}{l}\text { Lambda } \\
\text { bacteriophage }\end{array}$} & $\lambda-\mathrm{F}$ & CTGCGGCCTTTTACACATGA & \multirow[t]{2}{*}{$71 \mathrm{bp}$} & \multirow[t]{2}{*}{ SYBR Green } & \multirow[t]{2}{*}{$\lambda$ genome } & \multirow[t]{2}{*}{ This work } \\
\hline & $\lambda-\mathrm{R}$ & AAACGGCAGGAGGTTGTTAGC & & & & \\
\hline
\end{tabular}


For the pathogenicity tests, analyses of variance (ANOVA) were used to test for significant effects of independent variables, following a completely randomized design. Data from repeated experiments were previously subjected to an ANOVA and, since no statistical differences were found, the data of the two trials were combined into a single set of data. Percentage data were transformed (arcsine $\sqrt{ }$ Y/100) prior to analysis. Where significant $P$ values were determined, means were compared using Fisher's LSD test at the 95\% confidence level. All statistical analyses were performed with Statistix 9.0 (Analytical Software, Tallahassee, FL).

\section{Results}

Detection and quantification of $M$. phaseolina and $P$. cactorum in soil samples. Soil samples from nursery fields. M. phaseolina was detected in $47 \%$ ( 7 out of 15) of the fumigated soils and in $31 \%$ (6 out of 13) of the nonfumigated soils investigated in all localities and seasons. Average inoculum densities ranged from 1 to $30 \mathrm{pg}$ DNA/g soil in fumigated soils, and from 4 to $92 \mathrm{pg}$ DNA/g soil in nonfumigated soils (Fig. 1A). In plots investigated in Segovia, M. phaseolina was detected only in 1,3D:CP fumigated soils in the last cropping season. However, the pathogen was detected in all three seasons at variable levels in Ávila and Valladolid, with no significant differences evident between fumigated and nonfumigated plots. The inoculum reached the highest average concentration ( $92 \pm 37 \mathrm{pg}$ DNA/g soil) in nonfumigated plots from the Valladolid nursery in the last analyzed season (Fig. 1A).

P. cactorum was detected in $20 \%$ (3 out of 15 ) of the fumigated soils and in 54\% (7 out of 13) of the nonfumigated soils analyzed in the three provinces and seasons. Average inoculum densities were significantly higher in nonfumigated soils (ranging from 33 to 4,422 pg DNA/g soil) than in fumigated soils, having mean levels of between 183 and $986 \mathrm{pg}$ DNA/g soil. In the first investigated season, $P$. cactorum was detected only in a nonfumigated plot from Valladolid province (207 $\pm 114 \mathrm{pg}$ DNA/g soil) and not in fumigated soils. In

Table 2. Fusarium spp. isolates from soil and plant material obtained from strawberry nurseries and fruit production fields characterized in this study

\begin{tabular}{|c|c|c|c|c|c|c|c|}
\hline Species & Isolate & Origin $^{y}$ & Location & Source & Cultivar & Pathogenicity $^{\mathrm{z}}$ & Accession no. \\
\hline \multirow[t]{41}{*}{ F. oxysporum } & TOR-2 & FPF & Moguer & Preplanting soil & - & - & KX215004 \\
\hline & TOR-3 & FPF & Moguer & Preplanting soil & - & - & KX215005 \\
\hline & TOR-4 & FPF & Moguer & Root & Camarosa & - & KX215006 \\
\hline & TOR-6 & FPF & Moguer & Postharvest soil & - & nt & KX215007 \\
\hline & TOR-12 & FPF & Moguer & Root & Camarosa & nt & KX215008 \\
\hline & TOR-19 & FPF & Moguer & Crown & Camarosa & - & KX215009 \\
\hline & TOR-25 & FPF & Moguer & Root & Camarosa & nt & KX215010 \\
\hline & TOR-27 & FPF & Moguer & Root & Camarosa & - & KX215011 \\
\hline & TOR-29 & FPF & Moguer & Root & Camarosa & nt & KX215012 \\
\hline & TOR-30 & FPF & Moguer & Root & Camarosa & $\mathrm{nt}$ & KX215013 \\
\hline & TOR-31 & FPF & Moguer & Root & Camarosa & - & KX215014 \\
\hline & TOR-43 & FPF & Palos & Root & Camarosa & - & KX215015 \\
\hline & TOR-44 & FPF & Palos & Crown & Camarosa & nt & KX215016 \\
\hline & TOR-56 & FPF & Palos & Root & Camarosa & - & KX215017 \\
\hline & TOR-60 & FPF & Palos & Root & Camarosa & - & KX215018 \\
\hline & TOR-84 & FPF & Moguer & Root & Camarosa & - & KX215019 \\
\hline & TOR-85 & FPF & Moguer & Root & Camarosa & - & KX215020 \\
\hline & TOR-105 & NRP & Segovia & Root & Splendor & $\mathrm{nt}$ & nd \\
\hline & TOR-107 & NRP & Segovia & Root & Splendor & nt & nd \\
\hline & TOR-109 V & NRP & Segovia & Crown & Splendor & - & KX215021 \\
\hline & TOR-111 & NRP & Valladolid & Crown & Amiga & - & nd \\
\hline & TOR-112 & NRP & Valladolid & Crown & Amiga & - & nd \\
\hline & TOR-114 & NRP & Ávila & Crown & Festival & - & nd \\
\hline & TOR-115 V & NRP & Ávila & Crown & San Andreas & - & KX215022 \\
\hline & TOR-116 I & NRP & Ávila & Root & San Andreas & - & KX215023 \\
\hline & FPRE-1 & NRP & Ávila & Crown & Camarosa & nt & KX215024 \\
\hline & FPOST-3 & FPF & Palos & Root & Fortuna & - & KX215025 \\
\hline & FPOST-5 & FPF & Palos & Root & Fortuna & nt & KX215026 \\
\hline & FPOST-6 & FPF & Palos & Root & Fortuna & - & KX215027 \\
\hline & FPOST-11 & FPF & Palos & Root & Fortuna & - & KX215028 \\
\hline & FPOST-13 & FPF & Palos & Crown & Fortuna & - & KX215029 \\
\hline & FPOST-19 & FPF & Palos & Root & Fortuna & - & KX215030 \\
\hline & FPOST-21 & FPF & Palos & Root & Fortuna & - & KX215031 \\
\hline & FPOST-30 & FPF & Palos & Root & Fortuna & - & KX215032 \\
\hline & FPOST-36 & FPF & Palos & Root & Fortuna & - & KX215033 \\
\hline & FPOST-82 & FPF & Cartaya & Crown & Sabrina & - & KX215034 \\
\hline & FPOST-83 & FPF & Cartaya & Crown & Sabrina & - & KX215035 \\
\hline & FPOST-84 & FPF & Cartaya & Crown & Sabrina & - & KX215036 \\
\hline & FPOST-85 & FPF & Cartaya & Crown & Sabrina & - & KX215037 \\
\hline & FPOST-86 & FPF & Cartaya & Root & Sabrina & - & KX215038 \\
\hline & FPOST-91 & FPF & Cartaya & Crown & Sabrina & - & KX215039 \\
\hline
\end{tabular}

y FPF: Fruit production fields from Huelva province in southwestern Spain. NRP: Nursery runner plant. Nurseries were located at Segovia, Ávila, and Valladolid provinces in northern Spain.

${ }^{z}$ Pathogenicity test results of Fusarium species isolates that were artificially inoculated on strawberry plants, whereafter plant growth was evaluated after 3 months of growth in a growth chamber. The results are from two repeated experiments. Isolates were identified as nonpathogenic (-) when they did not cause a significant reduction in plant growth parameters relative to the uninoculated control plants, + indicates isolates that were identified as pathogenic since they caused a significant reduction in growth parameters relative to the uninoculated control plants; nt: not tested; nd: not determined. 
the two subsequent seasons, the pathogen was detected at highly variable levels in nonfumigated soils from Ávila (maximum average level 4,422 $\pm 1,921 \mathrm{pg}$ DNA/g soil) and Segovia (maximum average level 2,221 \pm 204 pg DNA/g soil) (Fig. 1B).

Soil samples from fruit production fields. M. phaseolina was detected in all fumigated preplant plots analyzed from Palos and showed a significant $(P \leq 0.05)$ increase in inoculum density (measured as pg DNA/g soil) at the end of each cropping season. Although the pathogen was not found in preplant fumigated plots in Cartaya in the last season, it appeared in all plots at the end of the seasons, being significantly higher in soils postharvest than in fumigated soils preplant $(P \leq 0.05)$ (Fig. 2A). M. phaseolina inoculum levels ranged from 35 to $373 \mathrm{pg}$ DNA/g soil in fumigated soils and between 62 and 1,568 pg DNA/g of soil in soils postharvest at the end of the seasons (Fig. 2A).

$P$. cactorum was first detected in Palos at the end of the 2011-12 season. In the following seasons, at this location the pathogen was found in soil, both in preplanted fumigated soil and in soils postharvest. The same pattern was found in Cartaya one year later, where $P$. cactorum was detected for the first time in Cartaya soils at the end of the 2012-13 season and, one year later, it was found in fumigated preplant soil and in soil of the postharvest plots (Fig. 2B). $P$. cactorum soil inoculum was lower than those of $M$. phaseolina, ranging from 2 to $3 \mathrm{pg}$ DNA/g soil before planting in the fumigated soil, and from 1 to $6 \mathrm{pg} \mathrm{DNA} / \mathrm{g}$ soil at the end of the season.

Fusarium spp. isolates, including $F$. oxysporum and $F$. solani, were recovered from preplant fumigated soil, and soils postharvest at the end of the cropping season in the three investigated seasons. Two $F$. oxysporum isolates recovered from soils postharvest were selected for pathogenicity testing, but none were pathogenic. However, the two selected $F$. solani isolates recovered from soils postharvest were pathogenic to strawberry (Table 2, see below).

Detection of $M$. phaseolina, P. cactorum, and Fusarium spp. in plant samples. Plant samples from nurseries. In mother plants, M. phaseolina and P. cactorum were not detected through qPCR analyses. However, isolates of Fusarium spp. were recovered by conventional isolation assays from $11.7,9.4$, and $12.1 \%$ of the analyzed mother plants in the 2011-12, 2012-13, and 2013-14 seasons, respectively (Table 3 ).

Table 2. (continued from preceding page)

\begin{tabular}{|c|c|c|c|c|c|c|c|}
\hline Species & Isolate & Origin $^{y}$ & Location & Source & Cultivar & Pathogenicity $^{\mathrm{z}}$ & Accession no. \\
\hline & FPOST-92 & FPF & Cartaya & Root & Sabrina & - & KX215040 \\
\hline & FPOST-140 & FPF & Cartaya & Crown & Fortuna & + & KX215041 \\
\hline & FPOST-143 & FPF & Cartaya & Crown & Fortuna & - & KX215042 \\
\hline & FPOST-162 & FPF & Cartaya & Crown & Fortuna & - & KX215043 \\
\hline & FPOST-166 & FPF & Cartaya & Crown & Sabrina & - & KX215044 \\
\hline & FPOST-170 & FPF & Cartaya & Crown & Sabrina & - & KX215045 \\
\hline & FPOST-172 & FPF & Cartaya & Crown & Sabrina & - & KX215046 \\
\hline & FPOST-179 & FPF & Palos & Crown & Splendor & - & KX215047 \\
\hline \multirow[t]{8}{*}{ F. solani } & TOR-393 & FPF & Moguer & Crown & Fortuna & + & KX215048 \\
\hline & TOR-397 & FPF & Moguer & Postharvest soil & - & + & KX215049 \\
\hline & TOR-725 & FPF & Moguer & Postharvest soil & - & + & KX215050 \\
\hline & E-III & FPF & Moguer & Crown & Camarosa & + & KX215056 \\
\hline & FPOST-164 & FPF & Cartaya & Root & Fortuna & - & KX215052 \\
\hline & FPOST-169 & FPF & Cartaya & Crown & Sabrina & + & KX215053 \\
\hline & FPOST-174 & FPF & Palos & Crown & Splendor & + & KX215054 \\
\hline & FPOST-176 & FPF & Cartaya & Crown & Fortuna & + & KX215055 \\
\hline \multirow[t]{11}{*}{ F. avenaceum } & FPOST-2 & FPF & Palos & Crown & Fortuna & - & KX215057 \\
\hline & FPOST-7 & FPF & Palos & Root & Fortuna & - & KX215058 \\
\hline & FPOST-10 & FPF & Palos & Crown & Fortuna & - & KX215059 \\
\hline & FPOST-16 & FPF & Palos & Crown & Fortuna & $\mathrm{nt}$ & KX215060 \\
\hline & FPOST-18 & FPF & Palos & Crown & Fortuna & - & KX215061 \\
\hline & FPOST-20 & FPF & Palos & Crown & Fortuna & nt & KX215062 \\
\hline & FPOST-35 & FPF & Palos & Root & Fortuna & $\mathrm{nt}$ & KX215062 \\
\hline & FPOST-40 & FPF & Palos & Crown & Fortuna & $\mathrm{nt}$ & KX215064 \\
\hline & FPOST-41 & FPF & Palos & Crown & Fortuna & nt & KX215065 \\
\hline & FPOST-43 & FPF & Palos & Root & Fortuna & $\mathrm{nt}$ & KX215066 \\
\hline & FPOST-48 & FPF & Palos & Crown & Fortuna & $\mathrm{nt}$ & KX215067 \\
\hline \multirow[t]{7}{*}{ F. acuminatum } & TOR-22 & FPF & Moguer & Crown & Camarosa & - & KX215068 \\
\hline & TOR-24 & FPF & Moguer & Crown & Camarosa & $\mathrm{nt}$ & KX215069 \\
\hline & TOR-26 & FPF & Moguer & Root & Camarosa & - & KX215070 \\
\hline & TOR-28 & FPF & Moguer & Root & Camarosa & - & KX215071 \\
\hline & TOR-32 & FPF & Moguer & Root & Camarosa & - & KX215072 \\
\hline & TOR-53 & FPF & Moguer & Crown & Camarosa & - & KX215073 \\
\hline & TOR-57 & FPF & Moguer & Root & Camarosa & - & KX215074 \\
\hline \multirow[t]{5}{*}{ F. proliferatum } & TOR-23 & FPF & Moguer & Crown & Camarosa & - & KX215075 \\
\hline & TOR-55 & FPF & Moguer & Root & Camarosa & - & KX215076 \\
\hline & TOR-115 III & NRP & Ávila & Crown & San Andreas & - & KX215077 \\
\hline & FPOST-90 & FPF & Cartaya & Crown & Sabrina & - & KX215079 \\
\hline & FPOST-117 & FPF & Cartaya & Crown & Fortuna & - & KX215080 \\
\hline \multirow[t]{4}{*}{ F. commune } & TOR-58 & FPF & Moguer & Root & Camarosa & - & KX215081 \\
\hline & TOR-115 IV & NRP & Ávila & Crown & San Andreas & - & KX215082 \\
\hline & TOR-116 IV & NRP & Ávila & Root & San Andreas & - & KX215083 \\
\hline & FPOST-153 & FPF & Cartaya & Crown & Fortuna & - & KX215084 \\
\hline \multirow[t]{3}{*}{ F. equiseti } & TOR-9 & FPF & Moguer & Root & Camarosa & - & KX215087 \\
\hline & TOR-45 & FPF & Moguer & Crown & Camarosa & - & KX215085 \\
\hline & FPOST-15 & FPF & Palos & Crown & Fortuna & - & KX215086 \\
\hline F. tricinctum & TOR-17 & FPF & Moguer & Root & Camarosa & - & KX215088 \\
\hline
\end{tabular}


Analyses of runner plants showed that $M$. phaseolina was not present, based on qPCR assays, in any of the investigated seasons (Table 3 ). In contrast, $P$. cactorum was detected in 1.2, 3.0, and $15.4 \%$ of runner plants in the 2011-12, 2012-13, and 2013-14 seasons, respectively (Table 3). Fusarium spp. isolates were recovered from conventional isolation assays in $16.9,16.5$, and $30 \%$ of the runner plants analyzed in the three seasons (Table 3). Nine of the Fusarium spp. isolates (six $F$. oxysporum, one $F$. proliferatum, and two $F$. commune) were included in the pathogenicity assays, but none were pathogenic (Table 2, see below).

Plants from fruit production fields. Over the study period, several isolates of $M$. phaseolina, $P$. cactorum, and Fusarium spp. were recovered by plate culturing from declining or dead plants, mainly from the selected macrotunnels in Cartaya and Palos, but also from different locations in Huelva province. The total percentage of symptomatic plants infected by M. phaseolina reached $4.2 \%$ in the investigated macrotunnels in the three seasons analyzed, reaching a maximum of $9.3 \%$ of plants infected with $M$. phaseolina in the Palos production field in the 2012-13 season. P. cactorum was isolated from $3.7 \%$ of the analyzed plants with maximum infection occurring in the Cartaya plots in the 2013-14 season (21.1\%). Seven percent of the plants contained Fusarium spp., with a maximum of $29.6 \%$ plants identified in the Cartaya plots in the 2013-14 season (Table 4). A total of 57 Fusarium spp. isolates were tested for pathogenicity, of which one $F$. oxysporum and five $F$. solani isolates were pathogenic (Table 2, see below).

Morphological and molecular characterization of Fusarium spp. Isolates identified by morphological characteristics were confirmed by sequencing of a portion of the $E F-1 \alpha$ gene. Fifty three percent of the 88 evaluated Fusarium spp. isolates were identified as $F$. oxysporum, $13 \%$ as $F$. solani, $12 \%$ as $F$. avenaceum, $7.6 \%$ as $F$. acuminatum, $5.4 \%$ as $F$. proliferatum, $4.3 \%$ as $F$. commune, $3.3 \%$ as $F$. equiseti, and $1.1 \%$ as $F$. tricinctum (Table 2 ).

Pathogenic characterization of Fusarium spp. isolates. Noninoculated control plants showed no symptoms during the experiments and no pathogens were reisolated. FPOST-140 was the only $F$. oxysporum isolate, obtained from a fruit production plant, which caused disease in strawberry plants from the $39 F$. oxysporum isolates tested (Table 2). Thirty seven percent of the plants died when inoculated with FPOST-140, and symptoms included a decrease in the development of new roots $(27 \%)$, crown necrosis $(16 \%)$, and a reduction in plant fresh weight $(33 \%)$ that differed significantly from the uninoculated control (Table 5). At the end of the experiment, FPOST-140 was reisolated from root, crown, and petiole tissues.

$F$. avenaceum, $F$. acuminatum, $F$. commune, $F$. equiseti, $F$. proliferatum, and $F$. tricinctum isolates did not cause disease symptoms in inoculated strawberry plants. Percentage of new roots, percentage of crown necrosis, and fresh plant weight of the plants inoculated with these isolates did not significantly differ from uninoculated controls (data not shown), although all were recovered from plant tissues at the end of the experiment. However, seven out of eight $F$. solani isolates recovered from fruit production field soils (TOR-393 and TOR-725) and diseased plants (TOR-397, FPOST-169, FPOST174, FPOST-176, and E-III) caused a significant reduction in the growth of strawberry plants (Table 6). The most aggressive $F$. solani isolate was TOR-393, which caused $100 \%$ mortality of the inoculated
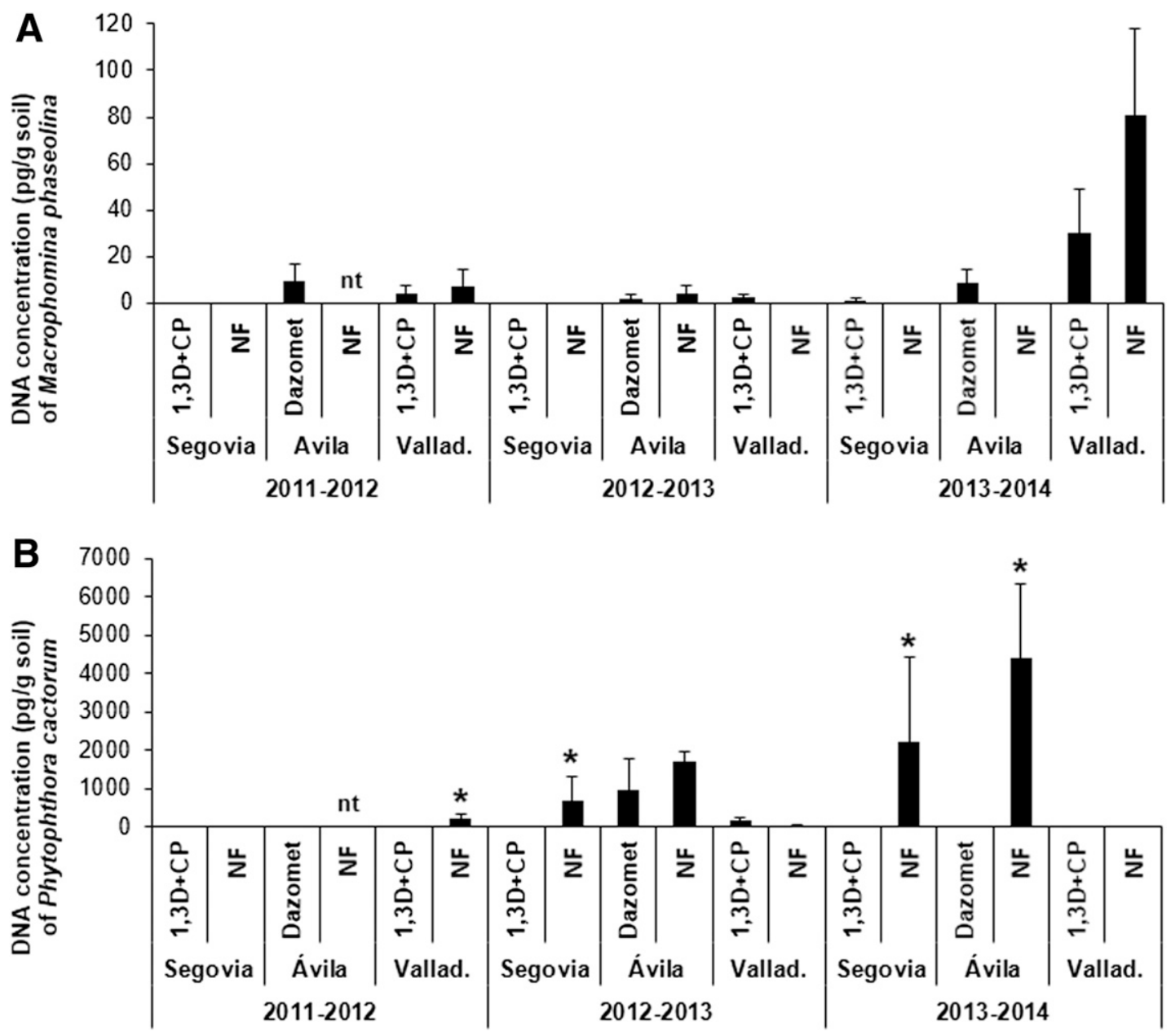

Fig. 1. Quantification of Macrophomina phaseolina (A) and Phytophthora cactorum (B) (pg DNA/g soil) in nursery soils from Segovia, Ávila, and Valladolid provinces in three consecutive strawberry seasons (2011-12, 2012-13, and 2013-14) by GPCR. Each bar is the average of two fumigated and two nonfumigated plots per location and season, except for Avila in 2012-13 and 2013-14 where just one fumigated and one nonfumigated plot was analyzed. NF: nonfumigated soils; 1,3D+CP: soils fumigated with 1,3dichloropropene:chloropicrin; Dazomet: soils fumigated with 3,5-dimethyl-1,3,5-thiadiazinane-2-thione. nt: not tested. Bars containing "*” differed significantly $(P=0.05)$ from the other treatments. Pairwise comparisons were done between fumigated and nonfumigated soils per location and season. 
plants, a $99 \%$ reduction of new roots, an $87 \%$ increase of crown rot, and a $34 \%$ decrease of fresh plant weight; all these parameters significantly different from uninoculated controls. Isolates TOR-725 and FPOST-169 caused 75\% plant mortality, and isolate TOR-397 caused $62.5 \%$ plant mortality. The rest of the $F$. solani isolates caused mortality in 38 to $50 \%$ of plants. This resulted in a significant decrease (50 to $75 \%$ ) in the percentage of new roots after transplanting and a significant reduction of fresh weight (64 to 81\%), compared with noninoculated control plants. The percentage of crown necrosis ranged from 21 to $87 \%$, being significantly higher than the uninoculated control (Table 6). Pathogenic F. solani isolates were reisolated from root, crown, and petiole tissues.
Specific PCR detection of $\boldsymbol{F}$. oxysporum f. sp. fragariae. The PCR assay yielded the expected $239 \mathrm{bp}$ band for the Japanese Fof reference isolate (MAFF 744009) (data not shown). None of the $F$. oxysporum isolates from declining strawberry plants from the current study were amplified using PCR primers FofraF and FofraR, which included the pathogenic Fof isolate FPOST-140. No amplifications were also obtained for the reference $F$ of isolates from Spain (G2-4), Australia (ATCC 18138), and South Carolina (NRRL 26438).

\section{Discussion}

The inoculum sources of the strawberry soilborne pathogens M. phaseolina and $P$. cactorum and the importance of F. oxysporum
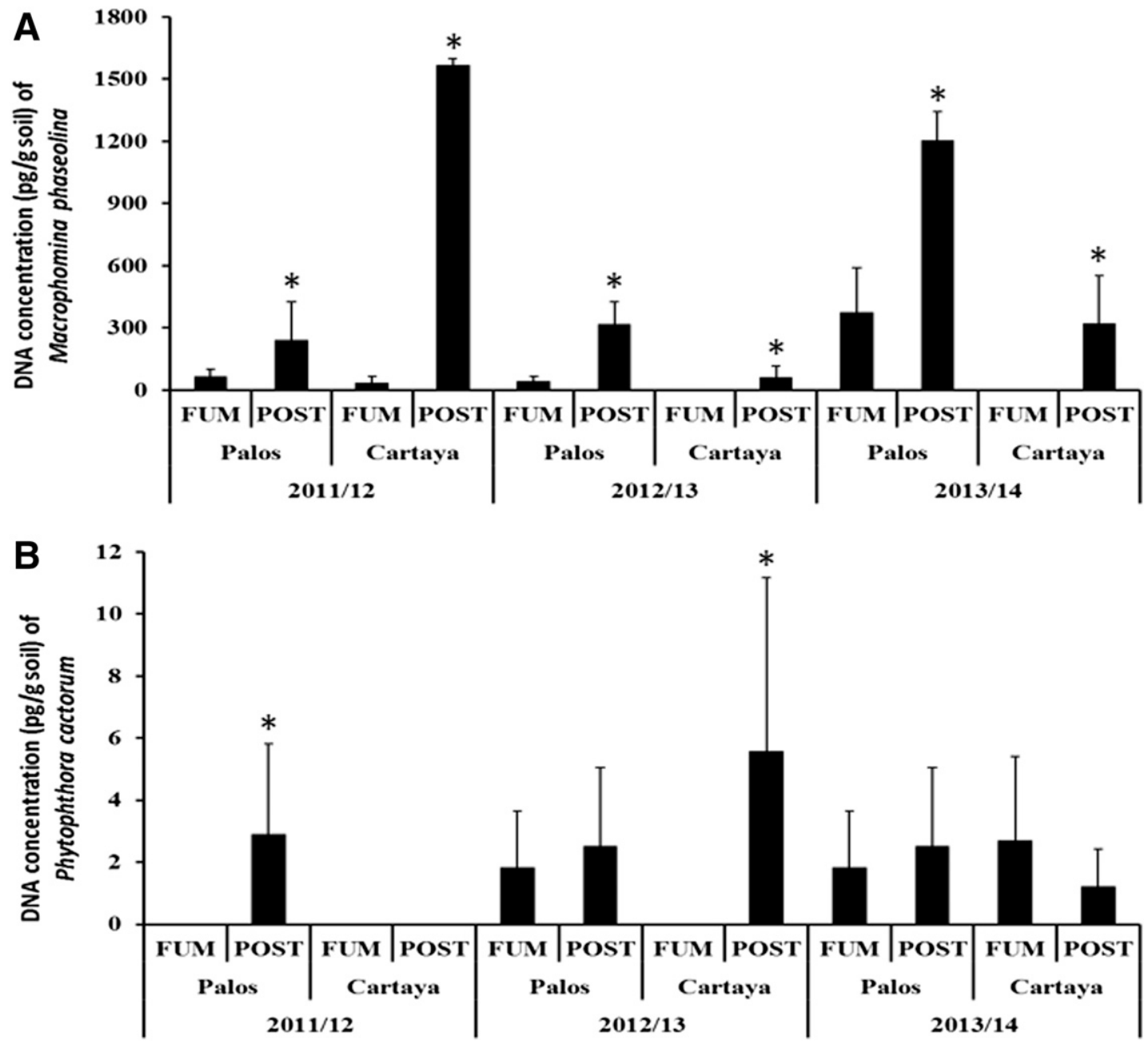

Fig. 2. Quantification of Macrophomina phaseolina (A) and Phytophthora cactorum (B) (pg DNA/g soil) in soils from two strawberry production fields of the Huelva province (Palos de la Frontera and Cartaya) in three consecutive seasons (2011-12, 2012-13, and 2013-14) by qPCR. Each bar is the average of three analyzed macrotunnels per location and season. FUM: Fumigated soils before planting (September-October); POST: Postharvest soils at the end of the production season (May-June). Bars containing "*" were significantly different $(P=0.05)$ from the other treatments. Pairwise comparisons were done between fumigated and nonfumigated soils per location and season.

Table 3. Percentage of nursery mother and runner plants from which Macrophomina phaseolina (MP) and Phytophthora cactorum (PC) were detected by qPCR, and from which Fusarium spp. (F) was obtained through isolation studies

\begin{tabular}{|c|c|c|c|c|c|c|c|c|c|c|c|c|c|}
\hline & \multirow[b]{2}{*}{$\begin{array}{l}\text { Nursery } \\
\text { province }\end{array}$} & \multicolumn{4}{|c|}{ 2011-12 } & \multicolumn{4}{|c|}{ 2012-13 } & \multicolumn{4}{|c|}{ 2013-14 } \\
\hline & & $\begin{array}{l}\text { No. plants } \\
\text { analyzed }\end{array}$ & MP & $P C$ & $F$ & $\begin{array}{l}\text { No. plants } \\
\text { analyzed }\end{array}$ & MP & $P C$ & $F$ & $\begin{array}{l}\text { No. plants } \\
\text { analyzed }\end{array}$ & MP & $P C$ & $F$ \\
\hline \multirow{4}{*}{$\begin{array}{l}\text { Mother } \\
\text { plants }\end{array}$} & Segovia & 100 & 0 & 0 & $6.0 \%(6 / 100)$ & 40 & 0 & 0 & $7.5 \%(3 / 40)$ & 42 & 0 & 0 & $14.3 \%(6 / 42)$ \\
\hline & Valladolid & 54 & 0 & 0 & $22.2 \%(12 / 54)$ & 60 & 0 & 0 & $10.0 \%(6 / 60)$ & 0 & - & - & - \\
\hline & Ávila & 160 & 0 & 0 & $11.9 \%(19 / 160)$ & 80 & 0 & 0 & $10.0 \%(8 / 80)$ & 165 & 0 & 0 & $11.5 \%(19 / 165)$ \\
\hline & Total & 314 & $\mathbf{0}$ & $\mathbf{0}$ & $11.7 \%(37 / 314)$ & 180 & $\mathbf{0}$ & $\mathbf{0}$ & $9.4 \%(17 / 180)$ & 207 & $\mathbf{0}$ & $\mathbf{0}$ & $12.1 \%(25 / 207)$ \\
\hline \multirow{4}{*}{$\begin{array}{c}\text { Runner } \\
\text { plants }\end{array}$} & Segovia & 131 & 0 & $2.3 \%(3 / 131)$ & $22.1 \%(29 / 131)$ & 70 & 0 & $4.3 \%(3 / 70)$ & $14.3 \%(10 / 70)$ & 216 & 0 & $16.2 \%(35 / 216)$ & $35.2 \%(76 / 216)$ \\
\hline & Valladolid & 66 & 0 & $0.0 \%(0 / 66)$ & $15.5 \%(10 / 66)$ & 20 & 0 & $5.0 \%(1 / 20)$ & $5.0 \%(1 / 20)$ & 41 & 0 & $7.3 \%(3 / 41)$ & $31.7 \%(13 / 41)$ \\
\hline & Ávila & 283 & 0 & $1.1 \%(3 / 283)$ & $14.8 \%(42 / 283)$ & 110 & 0 & $1.8 \%(2 / 110)$ & $20.0 \%(22 / 110)$ & 74 & 0 & $17.5 \%(13 / 74)$ & $17.6 \%(13 / 74)$ \\
\hline & Total & 480 & $\mathbf{0}$ & $1.2 \%(6 / 480)$ & $16.9 \%(81 / 480)$ & 200 & $\mathbf{0}$ & $3.0 \%(6 / 200)$ & $16.5 \%(33 / 200)$ & 340 & 0 & $15.4 \%(51 / 340)$ & $30.0 \%(102 / 340)$ \\
\hline
\end{tabular}


f. sp. fragariae and other Fusarium spp. in Spanish strawberry crops were investigated in soils and plant samples from Spanish nurseries and fruit production fields over three consecutive seasons. Sensitive and high throughput qPCR methods were applied for the specific detection and quantification of M. phaseolina and P. cactorum. The study indicated that ineffectively fumigated soils from nurseries and fruit production fields, and infected nursery runner plants, are the main sources of inoculum for some of these pathogens. F. solani was identified as the most important Fusarium spp. in fruit production fields.

M. phaseolina was detected in fumigated soils from nurseries and fruit production fields but not in nursery mother or runner plants. The fact that this pathogen could not be detected in runner plants could be due to inadequate environmental conditions and/or that the low inoculum density detected in nursery soils were below levels required for
M. phaseolina to cause infections. This phenomenon has previously been reported for $F$. oxysporum f. sp. fragariae (Koike and Gordon 2015), and it is thus possible that M. phaseolina could be present in the soil for several years without diseased plants being detected due to fumigation maintaining inoculum levels below levels that can cause disease. It could also be possible that the pathogen was not detected in runner plants since if the incidence in runner plants was very low, the sampling strategy would have resulted in infected runner plants not being sampled. For example, if 1,020 plants were tested, infection levels below $0.1 \%$ of plants would not be detected.

The presence of this pathogen in nursery soils may continue to be problematic, due to rotation crops used in nurseries, such as sunflower and leguminous species including soybean, being common hosts of this pathogen (Atiq et al. 2001; Dhingra and Sinclair

Table 4. Percentage of declining and dead strawberry plants from fruit production fields from which Macrophomina phaseolina, Phytophthora cactorum, and Fusarium spp. were detected through isolation studies

\begin{tabular}{|c|c|c|c|c|c|c|}
\hline \multirow[b]{2}{*}{ Locality } & \multirow[b]{2}{*}{ Season } & \multirow[b]{2}{*}{ No. plants sampled } & \multirow[b]{2}{*}{ No. symptomatic plants } & \multicolumn{3}{|c|}{ Percentage of infected plants ${ }^{\mathrm{z}}$} \\
\hline & & & & M. phaseolina & P. cactorum & Fusarium spp. \\
\hline \multirow[t]{3}{*}{ Cartaya } & $2011-12$ & 4,300 & 253 & $5.8(249 / 4,300)$ & $\boldsymbol{0 . 0}(0 / 4,300)$ & $2.3(101 / 4,300)$ \\
\hline & 2012-13 & 6,450 & 829 & $3.2(208 / 6,450)$ & $4.0(259 / 6,450)$ & $\mathbf{8 . 8}(567 / 6,450)$ \\
\hline & 2013-14 & 2,150 & 713 & $\mathbf{3 . 3}(72 / 2,150)$ & $21.1(453 / 2,150)$ & $\mathbf{2 9 . 6}(637 / 2,150)$ \\
\hline \multirow[t]{3}{*}{ Palos } & 2011-12 & 2,150 & 199 & $3.1(66 / 2,150)$ & $7.4(160 / 2,150)$ & $\mathbf{9 . 0}(194 / 2,150)$ \\
\hline & $2012-13$ & 4,300 & 420 & $9.3(399 / 4,300)$ & $\mathbf{0 . 0}(0 / 4,300)$ & $3.5(151 / 4,300)$ \\
\hline & 2013-14 & 4,300 & 6 & $\mathbf{0 . 0}(0 / 4,300)$ & $\mathbf{0 . 1}(2 / 4,300)$ & $\mathbf{0 . 1}(3 / 4,300)$ \\
\hline TOTAL & & 23,650 & 2,420 & 4.2 & 3.7 & 7.0 \\
\hline
\end{tabular}

${ }^{\mathrm{z}}$ Plants infected with M. phaseolina, P. cactorum, and Fusarium spp. in single or mixed infections.

Table 5. Mean disease incidence, percentage of newly emitted roots, percentage of crown rot, and plant fresh weight of 'Camarosa' strawberry plants inoculated with Fusarium spp. isolates grown under growth-chamber conditions ${ }^{\mathrm{y}}$

\begin{tabular}{|c|c|c|c|c|}
\hline Isolates & Dead plants (\%) & New roots $(\%)^{\mathrm{z}}(P=0.0001)$ & Crown $\operatorname{rot}(\%)^{\mathrm{z}}(P=0.0001)$ & Plant fresh weight $(\mathrm{g})^{\mathrm{z}}(P=0.0001)$ \\
\hline Control & 0 & $43.8 \pm 3.2 \mathrm{ab}$ & $0.0 \pm 0.0 \mathrm{a}$ & $8.2 \pm 0.8 \mathrm{a}$ \\
\hline \multicolumn{5}{|l|}{ F. commune } \\
\hline FPOST-153 & 0 & $38.8 \pm 3.9 \mathrm{abc}$ & $0.0 \pm 0.0 \mathrm{a}$ & $6.3 \pm 0.7 \mathrm{bcd}$ \\
\hline \multicolumn{5}{|l|}{ F. oxysporum } \\
\hline MAFF 744009 & 100 & $16.9 \pm 5.0 \mathrm{~d}$ & $66.25 \pm 16.5 \mathrm{c}$ & $1.6 \pm 0.2 \mathrm{f}$ \\
\hline NRRL 26438 & 62.5 & $20.0 \pm 3.5 \mathrm{~cd}$ & $18.8 \pm 14.0 \mathrm{~b}$ & $1.5 \pm 0.3 \mathrm{f}$ \\
\hline FPOST-140 & 37.5 & $31.9 \pm 9.3 \mathrm{~cd}$ & $16.3 \pm 12.1 \mathrm{~b}$ & $5.5 \pm 0.7 \mathrm{cde}$ \\
\hline FPOST-143 & 0 & $38.1 \pm 3.9 \mathrm{abc}$ & $0.0 \pm 0.0 \mathrm{a}$ & $7.3 \pm 0.6 \mathrm{abc}$ \\
\hline FPOST-162 & 0 & $53.8 \pm 4.5 \mathrm{a}$ & $0.0 \pm 0.0 \mathrm{a}$ & $7.0 \pm 0.5 \mathrm{abcd}$ \\
\hline FPOST-170 & 0 & $30.0 \pm 4.2 \mathrm{bc}$ & $0.0 \pm 0.0 \mathrm{a}$ & $4.4 \pm 0.4 \mathrm{e}$ \\
\hline FPOST-172 & 0 & $43.1 \pm 3.0 \mathrm{ab}$ & $0.0 \pm 0.0 \mathrm{a}$ & $6.8 \pm 0.6 \mathrm{abcd}$ \\
\hline FPOST-179 & 0 & $43.1 \pm 3.9 \mathrm{ab}$ & $0.0 \pm 0.0 \mathrm{a}$ & $5.4 \pm 0.6 \mathrm{de}$ \\
\hline \multicolumn{5}{|l|}{ F. proliferatum } \\
\hline FPOST-117 & 0 & $53.8 \pm 3.2 \mathrm{a}$ & $4.4 \pm 4.4 \mathrm{ab}$ & $7.6 \pm 0.8 \mathrm{ab}$ \\
\hline
\end{tabular}

y Growth chamber adjusted at $25 / 18^{\circ} \mathrm{C}$ and $60 / 40 \%$ relative humidity (day/night) and 16 -h photoperiod over 3 months.

${ }^{\mathrm{z}}$ Values are means \pm standard error of two experiments with eight plants per isolate. Different letters within columns indicate significant differences among treatments according to the LSD test $(P=0.05)$.

Table 6. Mean disease incidence, percentage of newly emitted roots, percentage of crown rot, and plant fresh weight of 'Camarosa' strawberry plants inoculated with Fusarium solani isolates grown under growth-chamber conditions ${ }^{\mathrm{y}}$

\begin{tabular}{lcccr}
\hline Isolates & Dead plants $(\boldsymbol{\%})$ & New roots $(\boldsymbol{\%})^{\mathbf{z}}(\boldsymbol{P}=\mathbf{0 . 0 0 0 3})$ & Crown $^{\text {rot }(\boldsymbol{\%})^{\mathbf{z}}(\boldsymbol{P}=\mathbf{0 . 0 0 0 1})}$ & Plant fresh weight $(\mathbf{g})^{\mathbf{z}}(\boldsymbol{P}=\mathbf{0 . 0 0 0 1})$ \\
\hline Control & $0(0 / 16)$ & $99.5 \pm 0.0 \mathrm{a}$ & $0.0 \pm 0.0 \mathrm{a}$ & $35.0 \pm 1.6 \mathrm{a}$ \\
TOR-393 & $100(16 / 16)$ & $0.5 \pm 0.0 \mathrm{~d}$ & $86.8 \pm 7.1 \mathrm{~d}$ & $2.3 \pm 0.2 \mathrm{c}$ \\
TOR-397 & $62.5(10 / 16)$ & $37.6 \pm 18.1 \mathrm{~cd}$ & $43.8 \pm 14.1 \mathrm{bc}$ & $9.4 \pm 3.8 \mathrm{bc}$ \\
TOR-725 & $75(12 / 16)$ & $25.3 \pm 16.2 \mathrm{~cd}$ & $53.1 \pm 14.6 \mathrm{bc}$ & $6.8 \pm 2.9 \mathrm{bc}$ \\
FPOST-164 & $0(0 / 16)$ & $87.1 \pm 10.5 \mathrm{ab}$ & $1.1 \pm 0.6 \mathrm{a}$ & $34.0 \pm 2.6 \mathrm{a}$ \\
FPOST-169 & $75(12 / 16)$ & $25.3 \pm 16.2 \mathrm{~cd}$ & $46.3 \pm 14.3 \mathrm{bc}$ & $6.9 \pm 2.9 \mathrm{bc}$ \\
FPOST-174 & $50(8 / 16)$ & $47.1 \pm 17.7 \mathrm{c}$ & $53.0 \pm 17.7 \mathrm{~cd}$ & $12.1 \pm 4.1 \mathrm{~b}$ \\
FPOST-176 & $50(8 / 16)$ & $50.0 \pm 18.7 \mathrm{bc}$ & $53.1 \pm 14.7 \mathrm{bcd}$ & $9.0 \pm 2.4 \mathrm{bc}$ \\
E-III & $50(8 / 16)$ & $50.0 \pm 50.0 \mathrm{bc}$ & $21.3 \pm 9.6 \mathrm{ab}$ & $12.7 \pm 3.5 \mathrm{~b}$ \\
\hline
\end{tabular}

${ }^{y}$ Growth chamber adjusted at $25 / 18^{\circ} \mathrm{C}$ and $60 / 40 \%$ relative humidity (day/night) and 16 -h photoperiod over 3 months.

${ }^{\mathrm{z}}$ Values are means \pm standard error of two experiments with eight plants per isolate. Different letters within columns indicate significant differences among treatments according to the LSD test $(P=0.05)$. 
1973) and thus acting as natural reservoirs. This is the first time $M$. phaseolina has been reported in nursery soils in Spain.

$P$. cactorum was detected in fumigated nursery and fruit production soils and also in nursery runner plants. The presence of $P$. cactorum in runner plants highlights the fact that these plants could be infected through ineffectively fumigated nursery soils and could thus be another source of inoculum for P. cactorum. An additional source of inoculum could be irrigation water, which was not investigated in the current study. Irrigation water has been shown in other crops to be an inoculum source of $P$. cactorum (Bienapfl and Balci 2014; Rivero et al. 2011).

Spanish certified strawberry plants, under the rules of the technical regulation of control and certification of nursery-grown fruit-bearing plants (BOE, 12 February 2011), are under legal obligation to be free of $P$. cactorum and other pathogens before sales. Due to this successful certification, all the analyzed mother plants were negative for $P$. cactorum. Although not identified in any of the mother plants analyzed, $P$. cactorum was detected in an increasing percentage of runner plants over the three seasons studied, which is a pathway for introduction of this pathogen into fruit production fields and which means that runner plants were infested through $P$. cactorumcontaminated nursery soils. In the present study, we have showed that the use of an easy sample preparation method joined to the sensitivity of qPCR could be a powerful tool for the preventative detection of $P$. cactorum in mother and runner plants by the regulatory authorities.

Fusarium spp. were detected in all the fruit production field soils analyzed and in a high percentage of plant material from nurseries and fruit production fields. This is not surprising since Fusarium spp. are common soil inhabitants and endophytes in plants (Kuldau and Yates 2000). The inoculum sources of Fusarium spp. could not be elucidated since most isolates tested for pathogenicity were obtained from diseased field production plants. The most abundant Fusarium species detected was F. oxysporum ( $56 \%$ of total Fusarium spp. analyzed) (Table 2). F. oxysporum f. sp. fragariae has been associated with crown and root disease of strawberry in Australia (Winks and Williams 1965), Asia (Okamoto et al. 1970), North America (Koike et al. 2009), and Europe (Stanković et al. 2014), causing devastating losses. In Spain, $F$. oxysporum f. sp. fragariae was reported in 2007, when wilted and dead strawberry plants were observed in a soilless culture system by Arroyo et al. (2009). Currently, the incidence of $F$. oxysporum f. sp. fragariae in Spanish strawberry crops seems to be low, since only one of $39 F$. oxysporum isolates tested in this study proved pathogenic to strawberry, even when a susceptible cultivar was used (Fang et al. 2012). The pathogenic isolate was recovered from the crown of a diseased plant from a fruit production field, but its inoculum source is unknown and could have originated from the production field soil or nursery plants. Plant material for generating mother plants comes largely from the U.S., where $F$. oxysporum f. sp. fragariae is a widespread pathogen that causes severe losses (Islas 2012; Koike and Gordon 2015). Since the use of infected plant material is one of the major causes of introducing a new pathogen into a cropping area, fast, sensitive, and specific detection methods are critical. Suga et al. (2013) developed a PCR assay to differentiate between strawberry-pathogenic and nonpathogenic $F$. oxysporum isolates. However, the only strawberrypathogenic isolate identified in the present study, FPOST-140, did not yield the diagnostic fragment described as being specific for $F$. oxysporum f. sp. fragariae. Similarly, other strawberrypathogenic isolates from culture collections analyzed in the present study including ATCC 18138 (Australia), G2-4 (Spain), and NRRL 26438 (South Carolina) did not yield the diagnostic amplicon. This result is consistent with findings of other studies where some strains that were identified as pathogens by pathogenicity testing did not yield the diagnostic fragment by PCR, and vice versa (Henry et al. 2017; Suga et al. 2013). Therefore, this molecular marker has proved to be useful for only a subset of $F$. oxysporum $\mathrm{f}$. $\mathrm{sp}$. fragariae populations. In addition, the PCR assay requires DNA extraction and agarose gel analyses, making it impractical for the analysis of a large number of samples. However, a quick and accurate method, as the described for
M. phaseolina and P. cactorum in this study, could be valuable for F. oxysporum f. sp. fragariae once a specific marker is described.

Our results on the pathogenic characterization of Fusarium spp. isolates recovered from field production plants and soil are important since it determined that $F$. solani is a new threat to strawberry production in Spain. Although most of the Fusarium species tested in this study did not cause disease in strawberry, special attention should be paid to the emerging pathogen $F$. solani to determine its current incidence and origin in Spain and other countries. This fungus, recently described as pathogenic to strawberry, was isolated from soil, asymptomatic runner plants from nurseries, and symptomatic plants from crop fields (Pastrana et al. 2014). The current study supports this finding, since a high percentage of $F$. solani isolates from fruit-production soil and diseased field plants were pathogenic to strawberry.

Early diagnosis and detection of strawberry pathogens in nursery soils and mother and runner plants is critical for disease control in fruit production fields to avoid the introduction, establishment, and spread of soilborne pathogens. In this study, qPCR methods were applied to soil samples and plant material for the specific detection and quantification of $M$. phaseolina and $P$. cactorum. The developed assays used DNA from soil and diluted crude plant extracts from asymptomatic or diseased plants. Inoculum levels in soil samples were measured as the amount of pathogen DNA/g of soil, which were able to detect levels of inoculum as low as $1 \mathrm{pg}$ DNA/g soil for $M$. phaseolina and $P$. cactorum. These low inoculum levels most likely originated from viable pathogen propagules, since DNA from dead fungi has been reported to be rapidly degraded and would thus have a limited contribution to the total DNA level (Herdina et al. 2004). The use of crude plant extracts constitutes a simple and direct sample-preparation method for real-time PCR, avoiding the DNAextraction step and allowing the high throughput analysis of a large number of plants. The use of a positive internal control in qPCR assays prevents the detection of false negatives, i.e., samples not amplified due to the presence of PCR inhibitors in the soil or plant extracts.

We conclude that ineffectively fumigated soils in nurseries and fruit production fields and infected runner plants can be sources of inoculum of some, but not all soilborne fungi and oomycetes that cause strawberry diseases in Spain. Preventive control measures such as the use of powerful molecular tools for the early and high throughput detection of fungal pathogens in mother and runner plants would be an effective strategy to decrease the introduction of pathogens into production fields that reduce yields. In addition, an integrated management strategy of these strawberry diseases should be considered including the use of resistant varieties (Avilés et al. 2009; Eikemo and Stensvand 2015), anaerobic disinfestation methods (Shennan et al. 2016), and biological control agents (Pastrana et al. 2016), which have shown potential for being effective nonchemical alternatives.

\section{Acknowledgments}

This work was supported by the INIA (Instituto Nacional de Investigación y Tecnología Agraria y Alimentaria) projects RTA2011-00011-00-00, cofinanced by the European Union through ERDF support: "Knowledge-Based Economy" Operational Programme, and RTA2013-00062-C05-02 cofinanced with 20142020 ERDF support: "Smart Growth" Operational Programme. A. M. Pastrana was a Ph.D. Fellow from the European Union and IFAPA (Consejería de Agricultura, Pesca y Desarrollo Rural, Junta de Andalucía). Authors would like to thank M. C. Sánchez, J. García, and A. Sánchez for technical assistance, Drs. B. De los Santos (IFAPA Las Torres-Tomejil) and M. Avilés (ETSIA) for providing cultures, and Dr. Margaret G. Lloyd and Dr. José M. Melero for critical reading of the manuscript.

\section{Literature Cited}

Arroyo, F. T., Llergo, Y., Aguado, A., and Romero, F. 2009. First report of Fusarium wilt caused by Fusarium oxysporum on strawberry in Spain. Plant Dis. 93:323.

Atiq, M., Shabeer, A., and Ahmed, I. 2001. Pathogenic and cultural variation in Macrophomina phaseolina, the cause of charcoal rot in sunflower. Sarhad J. Agric. 2:253-255

Avilés, M., Castillo, S., Bascón, J., Zea-Bonilla, T., Martín-Sánchez, P. M., and Pérez-Jiménez, R. M. 2008. First report of Macrophomina phaseolina causing crown and root rot of strawberry in Spain. Plant Pathol. 57:382. 
Avilés, M., Castillo, S., Borrero, C., Castillo, M. L., Zea-Bonilla, T., and PérezJiménez, R. M. 2009. Response of Strawberry Cultivars: 'Camarosa', 'Candonga' and 'Ventana' to Inoculation with Isolates of Macrophomina phaseolina. Pages 291-294 in: VI International Strawberry Symposium, 842.

Babu, B. K., Mesapogu, S., Sharma, A., Somasani, S. R., and Arora, D. K. 2011. Quantitative real-time PCR assay for rapid detection of plant and human pathogenic Macrophomina phaseolina from field and environmental samples. Mycologia 103:466-473.

Bienapfl, J. C., and Balci, Y. 2014. Movement of Phytophthora spp. in Maryland's nursery trade. Plant Dis. 98:134-144.

Capote, N., Pastrana, A. M., Aguado, A., and Sánchez-Torres, P. 2012. Molecular tools for detection of plant pathogenic fungi and fungicide resistance. Pages 151-202 in: Plant Pathology. C. J. Cumagun, ed. InTech, Rijeka, Croatia.

Chamorro, M., Miranda, L., Domínguez, P., Medina, J. J., Soria, C., Romero, F., López-Aranda, J. M., and De los Santos, B. 2015. Evaluation of biosolarization for the control of charcoal rot disease (Macrophomina phaseolina) in strawberry. Crop Prot. 67:279-286.

Cooke, D. E., Drenth, A., Duncan, J. M., Wagels, G., and Brasier, C. M. 2000. A molecular phylogeny of Phytophthora and related oomycetes. Fungal Genet. Biol. 30:17-32.

Corpas-Hervias, C., Melero-Vara, J. M., Molinero-Ruíz, M. L., Zurera-Muñoz, C., and Basallote-Ureba, M. J. 2006. Characterization of isolates of Fusarium spp. obtained from asparagus in Spain. Plant Dis. 90:1441-1451.

de los Santos, B., Porras, M., Blanco, C., Barrau, C., and Romero, F. 2002. First report of Phythophthora cactorum on strawberry plants in Spain. Plant Dis. 86:1051.

Dhingra, O. D., and Sinclair, J. B. 1973. Location of Macrophomina phaseolina on soybean plants related to cultural characteristics and virulence. Phytopathology 63:934-936.

Eikemo, H., and Stensvand, A. 2015. Resistance of strawberry genotypes to leather rot and crown rot caused by Phytophthora cactorum. Eur. J. Plant Pathol. 143: 407-413.

Fang, X. L., Kuo, J., You, M. P., Finnegan, P. M., and Barbetti, M. J. 2012. Comparative root colonisation of strawberry cultivars Camarosa and Festival by Fusarium oxysporum f. sp. fragariae. Plant Soil 358:75-89.

Gallegly, M. E., and Hong, C. 2008. Page 30 in: Phytophthora. Identifying Species by Morphology and DNA Fingerprints. APS Press, St. Paul, MN.

Henry, P. M., Kirkpatrick, S. C., Islas, C. M., Pastrana, A. M., Yoshisato, J., Koike, S. T., Daugovish, O., and Gordon, T. R. 2017. The population of Fusarium oxysporum f. sp. fragariae, cause of Fusarium wilt of strawberry, in California. Plant Dis. (in press). doi:10.1094/PDIS-07-16-1058-RE

Herdina, N. S., Neate, S., Jabaji-Hare, S., and Ophel-Keller, K. 2004. Presistence of DNA of Gaeumannomyces graminis var. tritici in soil as measured by DNAbased assay. FEMS Microbiol. Ecol. 47:143-152.

Inderbitzin, P., Harkness, J., Turgeon, B. G., and Berbee, M. L. 2005. Lateral transfer of mating system in Stemphylium. Proc. Natl. Acad. Sci. USA 102: 11390-11395.

Islas, C. M. 2012. Fusarium wilt caused by Fusarium oxysporum f. sp. fragariae: An emerging disease of strawberry in California. Thesis, Master of Science. University of California, Davis.

Koike, S. T., and Gordon, T. R. 2015. Management of Fusarium wilt of strawberry. Crop Prot. 73:67-72.

Koike, S. T., Kirkpatrick, S. C., and Gordon, T. R. 2009. Fusarium wilt of strawberry caused by Fusarium oxysporum in California. Plant Dis. 93:1077.

Kuldau, G. A., and Yates, I. E. 2000. Evidence for Fusarium endophytes in cultivated and wild plants. Pages 85-117 in: Microbial endophytes. C. W. Bacon and J. F. White Jr., eds. Marcel Dekker, New York.
Leslie, J. F., and Summerell, B. A., eds. 2006. The Fusarium laboratory manual, 1st Ed. Backwell Publishing, Ames, IA.

Li, M., Inada, M., Watanabe, H., Suga, H., and Kageyama, K. 2013. Simultaneous detection and quantification of Phytophthora nicotianae and P. cactorum, and distribution analyses in strawberry greenhouses by duplex real-time PCR. Microbes Environ. 28:195-203.

Li, Y., Mao, L., Yan, D., Ma, T., Shen, J., Guo, M., Wang, Q., Ouyang, C., and Cao, A. 2014. Quantification of Fusarium oxysporum in fumigated soils by a newly developed real-time PCR assay to assess the efficacy of fumigants for Fusarium wilt disease in strawberry plants. Pest Manag. Sci. 70:1669-1675.

Maas, J. L. 1998. Compendium of Strawberry Diseases, 2nd ed. APS Press, St. Paul, MN.

Martin, F. N. 2003. Development of alternative strategies for management of soilborne pathogens currently controlled with methyl bromide. Annu. Rev. Phytopathol. 41:325-350.

Mirmajlessi, S. M., Destefanis, M., Gottsberger, R. A., Mänd, M., and Loit, E. 2015. PCR-based specific techniques used for detecting the most important pathogens on strawberry: a systematic review. Syst. Rev. 4:9.

O’Donnell, K., Gueidan, C., Sink, S., Johnston, P. R., Crous, P. W., Glenn, A., Riley, R., Zitomer, N. C., Colyer, P., Waalwijk, C., Lee, Tv., Moretti, A., Kang, S., Kim, H. S., Geiser, D. M., Juba, J. H., Baayen, R. P., Cromey, M. G., Bithell, S., Sutton, D. A., Skovgaard, K., Ploetz, R., Corby Kistler, H., Elliott, M., Davis, M., and Sarver, B. A. 2009. A two-locus DNA sequence database for typing plant and human pathogens within the Fusarium oxysporum species complex. Fungal Genet. Biol. 46:936-948.

O’Donnell, K., Kistler, H. C., Cigelnik, E., and Ploetz, R. C. 1998. Multiple evolutionary origins of the fungus causing Panama disease of banana: concordant evidence from nuclear and mitochondrial gene genealogies. Proc. Natl. Acad. Sci. USA 95:2044-2049.

Okamoto, H., Fujii, S., Kato, K., and Yoshioka, A. 1970. A new strawberry disease 'Fusarium wilt'. Plant Prot. 24:231-235.

Pastrana, A. M., Basallote-Ureba, M. J., Aguado, A., Akdi, K., and Capote, N. 2016. Biological Control of strawberry soil-borne pathogens Macrophomina phaseolina and Fusarium solani, using Trichoderma asperellum and Bacillus spp. Phytopathol. Mediterr. 55:109-120.

Pastrana, A. M., Capote, N., De los Santos, B., Romero, F., and Basallote-Ureba, M. J. 2014. First report of Fusarium solani causing crown and root rot on strawberry crops in Southwestern Spain. Plant Dis. 98:161.

Pérez-Jiménez, R. M., De Cal, A., Melgarejo, P., Cubero, J., Soria, C., Zea-Bonilla T., and Larena, I. 2012. Resistance of several strawberry cultivars against three different pathogens. SJAR 10:502-512.

Rivero, V. I., Giayetto, A., Rossini, M., and Vera, D. 2011. Detection of Phytophthora cactorum in the irrigation water in commercial orchards of 'Bartlett' pear in Villa Regina, Rio Negro, Argentina. Acta Hortic. 909:521-526.

Shennan, C., Muramoto, J., Baird, G., Zavatta, M., Toyama, L., Mazzola, M., and Koike, S. T. 2016. Anaerobic soil disinfestation (ASD): a strategy for control of soil borne diseases in strawberry production. Acta Hortic. 1137:113-120.

Stanković, I., Ristić, D., Vučurović, A., Milojević, K., Nikolić, D., Krstić, B., and Bulajić, A. 2014. First report of Fusarium wilt of strawberry caused by Fusarium oxysporum in Serbia. Plant Dis. 98:1435.

Suga, H., Hirayama, Y., Morishima, M., Suzuki, T., Kageyama, K., and Hyakumachi, M. 2013. Development of PCR Primers to Identify Fusarium oxysporum f. sp fragariae. Plant Dis. 97:619-625.

Sutton, B. C. 1980. The Coelomycetes. CAB International, Kew, Surrey, U.K.

Winks, B. L., and Williams, Y. N. 1965. A wilt of strawberry caused by a new form of Fusarium oxysporum. Queensl. J. Agric. Anim. Sci. 22:475-479. 